\title{
EVALUATION OF SOME CROSSES FOR ECONOMIC TRAITS IN COTTON (GOSSYPIUM BARBADENSE L.)
}

\author{
EL-SEOUDY, ALIA A. ${ }^{1}$, N.Y. ABDEL-GHAFFAR ${ }^{1}$, H.Y. AWAD ${ }^{2}$, \\ A. ABDEL-HADY ${ }^{3}$ and SAWSAN I.M. DARWEESH ${ }^{2}$
}

1. Fac. of Agric., Ain Shams Univ., Giza

2. Cotton Res. Inst. A.R.C., Giza

3. Plant Pathol. Res. Inst. A.R.C., Giza

(Manuscript received 29 December 2013)

\begin{abstract}
This investigation was carried out to evaluate heterosis, combining ability, gene action and heritability of yield component traits for three commercial cotton varieties G90, G85 and G92 as female and three genotypes as male (G83x "G75x5844"), (G77xG70) and (G89xPima $\mathrm{S}_{6}$ ) using line $\mathrm{x}$ tester analysis. Results indicated that mean squares due to all 15 genotypes including parents and crosses were highly significant for all studied traits indicating the presence of sufficient genetic variability in this population. It was also found that parents vs. crosses mean squares as expressed to average heterosis over all crosses were highly significant for lint percentage and seed index. The mean performance of parents and their $F_{1}$ 's hybrids gave a wide range of variation for all studied traits. Heterotic values over the mid- and the better-parent varied between positive or negative significance and highly significant for most of the studied traits. The estimates of variance due to SCA were positive and higher in magnitude than the variance of GCA for all studied traits indicating that the nonadditive genetic effect played a major role in the genetic expression of these traits. While, additive effects had a minor role in the inheritance of these traits indicating that the hybridization program would be effective in improving yield and its components traits. Comparing the GCA effects of individual parent revealed that G83x(G75x5844) was the best combiner for all studied traits. Dominance estimates were higher than the additive estimates for all studied traits indicating more importance for dominant gene effect in the inheritance of these traits. Estimates of heritability in both broad and narrow senses for yield and its components showed high heritability values in broad sense were detected for all traits under investigation.
\end{abstract}

\section{INTRODUCTION}

Understanding of the genetic architecture of each breeding material is a matter of great interest for selecting the parent and crosses in order to establish the most efficient breeding program for attaining quick and maximum genetic improvement. Combining ability analysis among selected parents depends mainly on both types of gene action and the amount of potential genetic variability involved (Zeina et al.,2001, Abd El-Baky, 2006 and Sultan et al., 2013 ). The line x tester 
analysis is a systematic method of evaluating population or selected groups of inbred lines for combining ability in hybrid combinations. Studies on heterosis, combining ability, gene action and heritability for agronomic and economic traits in crosses of cotton were reviewed by many investigators (Ali, 2006, El-Feki et al., 2009, Saleh and Ali, 2012 and Sultan et al. 2013). This study was conducted to evaluate heterosis, combining ability, gene action and heritability for yield components traits. Six parents and their nine $F_{1} s$ were grown in a randomized complete block design at Agric. Res. Center and Agric. Res. Station at Sakha in two successive seasons 2009/2010 and 2010/2011.

\section{MATERIALS AND METHODS}

In the first season (2009/2010), the above mentioned Egyptian cotton varieties and genotypes were crossed following line $x$ tester technique. Genotypes (G83x "G75x5844"), (G77xG70) and (G89xPima $\mathrm{S}_{6}$ ) were used as male parents and varieties G90, G85 and G9 $r$ were used as female ones.

In the second season (2010/2011) the resulted seeds from the previous season $\left(F_{1}\right)$ were cultivated to evaluate heterosis, combining ability, gene action and heritability for yield and its components traits. All the normal cultural practices were applied as recommended for ordinary cotton cultivation. The yield of individual plants were harvested individually to determine the following traits:

1. Boll weight in grams (B.W. g): the average boll weight in grams of 50 bolls picked at random from each plot.

2. Number of bolls per plant: the average number of bolls for each plant.

3. Seed cotton yield (S.C.Y): estimated as the weight of seed cotton yield in kentar / Feddan (k/f).

4. Lint cotton yield (L.C.Y): estimated as the weight of lint cotton yield in kentar / Feddan (k/f).

5. Lint percentage (L \%). Ratio of lint to seed cotton yield expressed as percentage using the formula:

$$
L \%=\frac{\text { Weight of lint in sample }}{\text { Weight of seed cotton in the same sample }} \times 100
$$

6. Seed index in grams (S.I. g): as the weight of 100 seeds in grams taken at random from each plot.

7. Lint index in grams (L.I. g): as the weight of lint born on 100 seeds in grams. It was calculated according to the formula.

$$
\text { Lint index }=\frac{\text { Lint percentage } \% \mathrm{x} \text { seed index }}{100-\text { lint percentage }}
$$


The analysis of variance was done according to Cochran and Cox (1957). The significance of heterosis was determined using the least significant difference value (L.S.D.) at 0.05 and 0.01 levels of probability according to Steel and Torrie (1960), Line $x$ tester analysis as proposed by Kempthorne (1957) was used to partition the genetic variation of the $F_{1}$ top-crosses due to lines, testers and their interaction and provides information about general and specific combining ability of the parents and crosses, in addition, it provides the estimates of various types of gene effects. Finally, heritability was estimated in both broad $\left(\mathrm{h}^{2}\right)$ and narrow senses $\left(\mathrm{h}_{\mathrm{n}}^{2}\right)$ according to the formula given by Mather (1949).

\section{RESULTS AND DISCUSSION}

Differences in yield and yield components between studied varieties and genotypes were detected. Results of analysis of variance and the mean squares of yield and its components for six parents and their $9 \mathrm{~F}_{1}{ }^{\prime} \mathrm{s}$ crosses are presented in Table (1). Data showed that mean squares due to all 15 genotypes as well as mean square due to parents and crosses were highly significant for all studied traits indicating the presence of sufficient genetic variability in that population. In addition, data in Table (1) indicated that parents vs. crosses mean squares expressed as average heterosis over all crosses were highly significant for lint percentage and seed index. All crosses were found to be highly significant for all studied yield and its components traits. Similar conclusions were obtained by Abou El-Yazied (2004), Ali (2006) and El-Feki et al. (2009).

Table 1. Partioning of genotypes variance for yield and its components traits in top crosses mating design.

\begin{tabular}{|l|c|c|c|c|c|c|c|c|}
\hline \multicolumn{1}{|c|}{ S.O.V } & d.f. & BW & No.B/P & SCY/P & LY/P & L\% & SI & LI \\
\hline Rep. & 2 & 0.025 & 4.42 & 41.39 & 4.41 & 0.07 & 0.02 & 0.03 \\
\hline Geno. & 14 & $0.229 * *$ & $366.53 * *$ & $4728.11^{* *}$ & $641.72 * *$ & $8.49 * *$ & $0.88^{* *}$ & $0.92^{* *}$ \\
\hline Parents(P) & 5 & $0.177 * *$ & $360.86^{* *}$ & $5371.39 * *$ & $871.98^{* *}$ & $15.01 * *$ & $0.66 * *$ & $1.86^{* *}$ \\
\hline Crosses(C) & 8 & $0.286 * *$ & 415.66 & $4916.55^{* *}$ & $575.55 * *$ & $4.53 * *$ & $0.99 * *$ & $0.45^{* *}$ \\
\hline P vs. C & 1 & 0.035 & 1.89 & 4.24 & 19.82 & $7.60 * *$ & $1.021 * *$ & 0.047 \\
\hline Error & 28 & 0.025 & 20.70 & 109.71 & 15.70 & 0.21 & 0.06 & 0.028 \\
\hline
\end{tabular}

$*$, ** Significant and highly significant $(\mathrm{P}<0.05, \mathrm{P}<0.01$, respectively).

\section{Mean performance:}

The mean performance of parents and their $F_{1}$ 's hybrids for yield and its components traits are shown in Table (2) from which a wide range of variation for all traits could be observed.

Regarding the female parents, G92 gave the highest mean performance for all studied traits except lint percentage. While G85 gave the lowest mean performance 
for boll weight, number of bolls per plant, seed cotton yield/plant and lint yield/plant. In addition, G90 gave the lowest mean performance for lint percentage and lint index. Both G90 and G85 gave the same lowest mean performance for seed index (10.17). On the other hand, G90 gave intermediate mean performance for boll weight, number of bolls/plant, seed cotton yield/plant and lint yield/plant. While, G85 gave intermediate mean values for lint percentage and lint index.

Mean performance for male parents varied between high and low values. G83x "G75xG5844" gave the highest mean performance for boll weight, number of bolls/plant, seed cotton yield/plant, lint yield/plant and seed index while, it gave the lowest mean values for lint percentage and lint index. G77xG70 gave the lowest mean performance for all traits except for lint percentage which was the highest. Meanwhile, G89xPima $S_{6}$ gave intermediate mean male performance for all traits except for lint index which was the highest.

Table 2. The mean performance for 3 parental lines, 3 testers and their $F_{1}$ hybrids in top cross for yield and its components traits.

\begin{tabular}{|c|c|c|c|c|c|c|c|}
\hline Genotypes & BW & NO.B/P & SCY/P & LY/P & L\% & SI & LI \\
\hline G92 & 3.443 & 54.86 & 188.92 & 76.62 & 37.00 & 11.05 & 6.49 \\
\hline G90 & 2.960 & 41.29 & 122.20 & 41.39 & 38.50 & 10.17 & 6.37 \\
\hline G85 & 2.753 & 38.82 & 106.80 & 40.76 & 38.15 & 10.17 & 6.27 \\
\hline G83x "G75x5844" & 3.127 & 62.42 & 194.35 & 70.13 & 36.08 & 10.23 & 5.78 \\
\hline G77xG70 & 2.867 & 32.61 & 93.50 & 35.34 & 37.78 & 9.58 & 5.82 \\
\hline G89xPima S6 & 2.943 & 46.48 & 135.07 & 50.30 & 37.25 & 10.20 & 6.06 \\
\hline G92x(G83x "G75x5844") & 3.188 & 65.08 & 207.50 & 72.60 & 35.00 & 11.33 & 6.10 \\
\hline G92x(G77xG70) & 2.95 & 55.68 & 163.71 & 56.24 & 34.35 & 10.68 & 5.59 \\
\hline G92 x(G89xPima S6) & 3.21 & 55.67 & 178.81 & 64.01 & 35.80 & 11.07 & 6.17 \\
\hline G90 x(G83x"G75x5844") & 2.834 & 48.39 & 136.71 & 51.80 & 37.88 & 10.13 & 6.18 \\
\hline G90 x(G77xG70) & 2.78 & 39.64 & 110.32 & 40.94 & 37.14 & 9.78 & 5.78 \\
\hline G90 x(G89xPima S6) & 3.45 & 33.70 & 116.04 & 42.98 & 37.03 & 10.37 & 6.10 \\
\hline G85 x(G83x"G75x5844") & 3.611 & 44.65 & 161.08 & 61.03 & 37.89 & 11.29 & 6.89 \\
\hline G85 x(G77xG70) & 2.74 & 27.98 & 76.72 & 28.16 & 36.74 & 10.19 & 5.92 \\
\hline G85 x(G89xPima S6) & 2.90 & 40.15 & 116.00 & 41.87 & 36.10 & 10.02 & 5.66 \\
\hline LSD 5\% & 0.264 & 7.616 & 17.532 & 6.632 & 0.762 & 0.401 & 0.280 \\
LSD 1\% & 0.355 & 10.254 & 23.605 & 8.928 & 1.026 & 0.541 & 0.376 \\
\hline
\end{tabular}

According to parental combinations, mean performance for $F_{1}$ hybrids varied for all studied traits. G92x (G83x "G75x5844") gave the highest mean performance for number of bolls/plant, seed cotton yield/p, lint yield/p and seed index. Meanwhile, G85 x (G83x "G75x5844") gave the highest mean performance for boll weight, lint percentage and lint index. On the other hand, G85x (G77xG70) gave the lowest mean performance for boll weight, number of bolls $/ p$, seed cotton yield $/ p$ and lint yield $/ p$, while G92 x(G77xG70)gave the lowest means for lint percentage and lint index. Meanwhile, G90x(G77xG70) gave the lowest mean performance for only seed index.

Four $F_{1}$ crosses gave intermediate mean performance, namely, G92 $x$ (G77xG70) for boll weight, G90x(G83x "G75x5844") for seed cotton yield/plant and lint yield/plant, G90 x (G89xPimaS $\left.{ }_{6}\right)$ for seed and lint index, G85x(G83x "G75x5844") for number of bolls/plant and G85x(G77xG70) for lint percentage. These results were in agreement with those obtained by Ali (2006) and Saleh and Ali (2012). 


\section{Heterosis:}

Heterosis is a result of partial dominance, complete dominance, over dominance, epistasis and combination of all these factors. Heterosis and useful heterosis were expressed as the percentage deviations of $F_{1}$ mean performance from mid-parent and better-parent for yield and its components traits in each cross and values are presented in Table (3).

None of the crosses gave positive significant heterotic values over the better parent for number of bolls/plant, seed cotton yield/plant, lint yield/plant, lint percentage and lint index. For boll weight, G90 x (G89 x Pima $\left.\mathrm{S}_{6}\right)$ recorded highly significant and positive heterotic values over the mid- and better-parent while $G 92 \mathrm{x}$ (G89xPima $\mathrm{S}_{6}$ ) and $\mathrm{G} 85 \times(\mathrm{G} 83 \times$ "G75x5844") recorded significant and positive heterotic values over the mid- and better-parent. Regarding number of bolls/plant, four crosses gave positive significant heterotic values over the mid-parent, namely, G92x (G83x "G75x5844"), G92 x (G77xG70), G92 x (G89xPimaS 6 ) and G90 x (G83x "G75x5844"), while none of the crosses showed positive significant values over the better-parent. Meanwhile, G92 x (G83x "G75x5844"), G92x (G89xPima S 6 ) and G90 x (G89 x Pima $\mathrm{S}_{6}$ ) recorded highly significant and positive heterotic values over the midparent for seed cotton yield/plant. As for lint yield/plant, G92 x (G89xPimaS $\left.{ }_{6}\right)$ and G90 $\mathrm{x}\left(\mathrm{G} 89 \times\right.$ Pima $\left.\mathrm{S}_{6}\right)$ recorded highly significant and significant positive heterotic values over the mid-parent, respectively. Regarding lint percentage, G90 x(G77xG70) and G85 x(G77xG70) recorded highly significant and positive heterotic values over the mid-parent. Five crosses recorded highly significant and positive heterotic values over the mid-parent for seed index, namely, G92 x (G83x "G75x5844"), G92 x(G77xG70), G92 x (G89 x Pima S 6 ), G90x (G89xPima S S $_{6}$ and G85 x (G83x "G75x5844"), while G92 x(G77xG70) and $\mathrm{G} 92 \times\left(\mathrm{G} 89 \times\right.$ Pima $\left.\mathrm{S}_{6}\right)$ recorded significant and highly significant and positive heterotic values over the better-parent, respectively. For lint index, G92x (G89 x Pima $\mathrm{S}_{6}$ ) recorded significant values and G90 x (G77xG70) and G85 $x(G 77 x G 70)$ recorded highly significant and positive heterotic values over the midparent. The presence of heterosis over mid- and better-parent could be due to the genetic diversity between used materials. Superiority of $F_{1}$ crosses over mid-parental values is further evidence of non additive gene effects for studied traits. These findings are in agreement with those of Abo El-Yazied (2004), Ali (2006) and Saleh and Ali (2012). 
Table 3. Heterosis\% over mid parent (M.P.) and better parent (BP) for yield and its components traits.

\begin{tabular}{|c|c|c|c|c|c|c|c|c|c|c|c|c|c|c|}
\hline \multirow{2}{*}{ Genotypes } & \multicolumn{2}{|c|}{ BW } & \multicolumn{2}{|c|}{ No.B/P } & \multicolumn{2}{|c|}{$\mathrm{SCY} / \mathrm{P}$} & \multicolumn{2}{|c|}{$\mathrm{LY} / \mathrm{P}$} & \multicolumn{2}{|c|}{$L \%$} & \multicolumn{2}{|c|}{ SI } & \multicolumn{2}{|c|}{$\mathrm{LI}$} \\
\hline & $\mathrm{MP}$ & $\mathrm{BP}$ & MP & $\mathrm{BP}$ & MP & $\mathrm{BP}$ & MP & $\mathrm{BP}$ & $\mathrm{MP}$ & $\mathrm{BP}$ & MP & $\mathrm{BP}$ & MP & $\mathrm{BP}$ \\
\hline 1 & -2.95 & $-7.413^{*}$ & $10.98 *$ & 4.257 & $8.28^{* *}$ & 6.77 & -1.06 & -5.25 & $-8.67 * *$ & $-13.70 * *$ & $6.49 * *$ & 2.55 & $-8.37 * *$ & $-19.08^{* *}$ \\
\hline 2 & -3.11 & -5.696 & 7.39* & -10.794 & 3.43 & $-15.77 * *$ & 0.86 & $-19.81 * *$ & $-1.73 *$ & $-4.79 * *$ & $4.73 * *$ & $4.39 *$ & 1.90 & -3.22 \\
\hline 3 & $9.30 * *$ & 2.772 & 9.98* & -10.819 & $18.75^{* *}$ & -7.99 & $15.44 * *$ & -8.73 & $-3.56^{* *}$ & $-6.17 * *$ & $8.54 * *$ & $8.19 * *$ & $2.50 *$ & -1.52 \\
\hline 4 & $-10.17 * *$ & $-17.688 * *$ & $10.65^{*}$ & -11.789 & -3.19 & $-27.64 * *$ & $-7.46 *$ & $-32.39 * *$ & $-3.30 * *$ & $-6.60 * *$ & $-1.76 *$ & $-8.28^{* *}$ & $-7.47 * *$ & $-18.02 * *$ \\
\hline 5 & $-4.73 *$ & -6.231 & 7.29 & -3.987 & 2.29 & -9.73 & 6.72 & -1.08 & $3.72 * *$ & -1.70 & -1.00 & -3.84 & $4.87 * *$ & -0.75 \\
\hline 6 & $22.60 * *$ & $20.177 * *$ & -5.64 & -13.179 & $15.87^{* *}$ & 8.65 & $12.96 *$ & 5.45 & $-2.45^{* *}$ & $-2.92 * *$ & $5.03 * *$ & 2.01 & 0.94 & -2.68 \\
\hline 7 & $13.09 * *$ & 4.877 & $-11.88^{*}$ & $-18.607 *$ & -0.57 & $-14.74 * *$ & -3.84 & $-20.35^{* *}$ & $-2.59 * *$ & $-6.56 * *$ & $6.27 * *$ & 2.18 & 1.37 & $-8.60 * *$ \\
\hline 8 & $-7.12 *$ & -7.379 & $-36.24 * *$ & $-39.797 * *$ & $-40.36 * *$ & $-43.20 * *$ & $-38.58 * *$ & $-44.02 * *$ & $3.37 * *$ & -1.37 & 0.06 & -0.10 & $5.27 * *$ & -2.21 \\
\hline 9 & 1.73 & -1.548 & -5.86 & -13.624 & -4.07 & $-14.12 * *$ & $-8.04 *$ & $-16.77 *$ & $-4.26 * *$ & $-5.39 * *$ & -1.62 & -1.78 & $-8.19 * *$ & $-9.75 * *$ \\
\hline
\end{tabular}

$*$, ** Significant and highly significant $(\mathrm{P}<0.05, \mathrm{P}<0.01$, respectively).
$1=$ G92x(G83x "G75x5844")
$2=\mathrm{G} 92 \times(\mathrm{G} 77 \times \mathrm{G} 70)$
$3=\mathrm{G} 92 \times\left(\mathrm{G} 89 \times \mathrm{Pima}_{6}\right)$
4= G90 x(G83x "G75x5844")
$5=\mathrm{G} 90 \times(\mathrm{G} 77 \times \mathrm{G} 70)$
$6=\mathrm{G} 90 \times\left(\mathrm{G} 89 \times \mathrm{Pima} \mathrm{S}_{6}\right)$
7= G85 x (G83x "G75x5844")
$8=\mathrm{G} 85 \times(\mathrm{G} 77 \times \mathrm{G} 70)$
$9=\mathrm{G} 85 \times\left(\right.$ G89xPima $\left.\mathrm{S}_{6}\right)$ 


\section{Combining ability and gene action:}

General combining ability (GCA) could be defined as the average performance of the genotypes in the crosses involving these genotypes. The results in Table (4) showed that variances due to both males (tester) and females (line) were insignificant for boll weight, seed index and lint index. Variances due to female (line) were highly significant for number of bolls per plant and seed cotton yield per plant, and was significant for lint yield per plant and lint percentage. On the other hand, the variances due to testers (male) were significant for seed cotton yield and lint yield per plant.

Line $\mathrm{x}$ tester interactions were found to be highly significant for all yield and its components traits except for number of bolls per plant (significant), indicating that lines (females) didn't express similar orders of ranking according to performance of their crosses with the three testers (males).

Low ratio of GCA/SCA for boll weight, number of bolls per plant, seed cotton and lint yield and seed and lint indexes indicated that specific combining ability was more important than general combing ability.

Table 4. Partitioning of genetic variance of the crosses to its components, general and specific combining ability effects for yield and its components traits.

\begin{tabular}{|c|c|c|c|c|c|c|c|c|}
\hline S.O.V. & d.f & BW & NO.B/P & SCY/P & LY/P & L\% & SI & LI \\
\hline Lines & 2 & 0.0225 & $1187.42^{* *}$ & $12257.60^{* *}$ & $1183.738^{*}$ & $13.435^{*}$ & 1.98 & 0.096 \\
\hline Testers & 2 & 0.4265 & 344.71 & $6069.42^{*}$ & $916.755^{*}$ & 1.707 & 1.13 & 0.913 \\
\hline L x T & 4 & $0.3474 * *$ & $65.25 *$ & $669.59 * *$ & $100.844 * *$ & $1.487 * *$ & $0.45^{* *}$ & $0.394 * *$ \\
\hline Error & 28 & 0.0248 & 20.70 & 109.71 & 15.697 & 0.207 & 0.06 & 0.028 \\
\hline GCA & & 0.4301 & 59.39 & 746.50 & 113.530 & 1.706 & 0.52 & 0.489 \\
\hline SCA & & -0.011 & 24.75 & 302.19 & 33.296 & 0.198 & 0.03 & -0.003 \\
\hline GCA/SCA & & 0.000 & 2.40 & 2.47 & 3.410 & 8.624 & 15.71 & 0.000 \\
\hline Additive & & -0.022 & 49.496 & 604.379 & 66.591 & 0.396 & 0.066 & -0.006 \\
\hline Dominance & & 0.430 & 59.392 & 746.504 & 113.530 & 1.706 & 0.516 & 0.489 \\
\hline Error & & 0.0083 & 6.9010 & 36.5714 & 5.2323 & 0.0691 & 0.0192 & 0.0093 \\
\hline
\end{tabular}

*, ** Significant and highly significant $(\mathrm{P}<0.05, \mathrm{P}<0.01$, respectively).

The analyzed data revealed that dominance estimates were higher than the additive estimates for all yield and its components traits. These results revealed that the nature of the gene effect was predominantly non additive (dominance). This would indicate the importance of crossing programs for the improvement of the desired traits. The obtained results were in harmony with those previously obtained by Rady (1999), Soliman (1999) and Zhang et al., (2003). 


\section{Heritability estimates:}

Estimation of heritability depends on the amount of total genetic variance with respect to phenotypic variance. When the total genetic variance is mostly additive in nature these estimates would be narrow senses heritability $\left(h^{2}\right)$, but if the genetic variance included both additive and non-additive types of genetic variance, the estimates would be a broad sense heritability $\left(\mathrm{h}^{2} \mathrm{~b}\right)$. These two types of heritability are important to the breeder as they offer an indicator about the successful breeding program that should be followed. Therefore, large estimates of heritability specially in the narrow sense indicate the effectiveness of selection for improvement. Both narrow and broad senses heritabilities become close to each other when non-additive genetic variance are small in magnitude.

Heritability in the broad and narrow senses is shown in Table (5). Estimates of heritability in both broad and narrow senses for yield and its component indicated that high heritability values in broad senses were detected for all traits under investigation revealing that phenotypic selection for these traits could be highly effective. Minor values of narrow sense heritability for boll weight and lint index indicated that the additive gene action was negligable. The narrow sense heritability values indicated that non additive gene action were low for seed index and lint percentage. On the other hand, the narrow sence heritability gave high value for number of bolls per plant, seed cotton yield per plant and lint yield per plant and seed cotton yield/plant indicating the importance of additive gene action for inheritance of these traits. Data showed that female contributions were relatively equal to male contributions for boll weight. The male contributions were higher than female contributions for seed cotton and lint yield, seed index and lint index. Female contributions were higher than male contribution for lint percentage. The contributions of line $\times$ tester interaction were higher than both male and female contributions for seed cotton and lint yield and boll weight. The contribution of line $\times$ tester interaction was lower than both line and tester contributions for lint percentage. These results were in agreement with those obtained by El-Helw et al., (2002), Zeina (2002), Hassan (2004) and Saleh and Ali (2012). 
Table 5. Mean variances for of lines, testers and their interaction in $F_{1}$ crosses and heritability in the broad and narrow sense for studied traits.

\begin{tabular}{|c|c|c|c|c|c|c|c|}
\hline Source & BW & \# B/P & SCY/P & LY/P & L\% & SI & LI \\
\hline Lines & 0.023 & $1187.42 * *$ & $12257.6 * *$ & $1183.74 *$ & $13.435^{*}$ & 1.976 & 0.096 \\
\hline Testers & 0.427 & 344.714 & $6069.42^{*}$ & $916.76^{*}$ & 1.707 & 1.932 & 0.913 \\
\hline LXT & $0.347 * *$ & $65.247 *$ & $669.59 * *$ & $100.84 * *$ & $1.487 * *$ & $0.445 * *$ & $0.394 * *$ \\
\hline$h^{2}{ }_{b}$ & 98.110 & 94.04 & 97.36 & 97.18 & 96.81 & 96.81 & 98.13 \\
\hline$h^{2}$ & 0.00 & 42.75 & 43.56 & 35.93 & 18.23 & 10.93 & 0.00 \\
\hline
\end{tabular}

$*$, ** Significant and highly significant $(\mathrm{P}<0.05, \mathrm{P}<0.01$, respectively).

It could be concluded that the breeding program should be directed to develop elite lines through selection from the segregation of the promising $F_{1}$ hybrids. Later on, these lines would be utilized in the production of superior hybrids.

\section{REFERENCES}

1. Abd El-Baky, A.M. 2006. Genetic consequencies of incorporating 40 foreign genes into some Egyptian cotton. M. Sc. Thesis Fac. of Agric. Zagazig Univ., Egypt, pp. 100.

2. Abou El-Yazied, M.A. 2004. Bochemical analysis as a tool to the prediction of heterosis and combining ability in some cotton crosses.Ph.D. Thesis, Fac. of Agric. Mansoura, Univ., Egypt.Ali-Samia, E.S. (2006). Relationship of some cotton genotypes by insect resistance. Ph.D. Thesis, Inst. of Environ. Studies and Res., Ain Shams Univ., Egypt PP 109.

3. Ali-Samia, E.S. 2006. Relationship of some cotton genotypes by insect resistance. Ph.D. Thesis, Inst. of Environ. Studies and Res., Ain Shams Univ., Egypt PP 109.

4. Cochran, W.C. and G.M. Cox. 1957. Experimental design. $2^{\text {nd }}$ ed., John Wiley and Sons Inc., New York. U.S.A.

5. El-Feki, T.A, R.K. Harb and Aziza-Sultan, M. 2009. Heterosis and gene action for partial diallel crosses in cotton: 1 - Cotton insect resistance and multivariate analysis for traits related to insect resistance. Egypt J. Agric. Res., 87 (4): 11191134.

6. El-Helw, S.S.H., M.A.M. Allam, Hanem A. Mohamed and M.A. Abd El-Gelil, 2002. Estimation of stability and genetic parameters for some characters of Egyptian extra-long staple genotypes. J. Agric. Sci. Mansoura Univ., 27(8): 5303-5314.

7. Hassan, H.A.E. 2004. Study of combining ability for top crosses in cotton. M.Sc. Thesis, Al-Azhar Univ. Egypt. 
8. Kempthorne, O. 1957. An introduction to genetic statistics. Iowa state Univ. John Wiley and Sons Inc. New York, U.S.A. 545 pp.

9. Mather, K. 1949. Biometrical genetics. $1^{\text {st }}$ ed. Methuem, London.

10. Rady, M.S., F.A. Hendawy, A.M. Abd El-Hamid and R.M. Esmail, 1999. Combining ability of yield and yield components in cotton. Egypt. J. Agron. Vol. 21, 53-66.

11. Saleh, Eman M.R.M. and Ali, Samia E. 2012. Diallel analysis for yield components traits and fiber traits in cotton. Egypt. J. Plant Breed. 16 (2): 65-77.

12. Soliman, Y.A.M. 1999. Studies on some economic characters in some cotton crosses., M.Sc. Thesis, Fac. of Agric. Kafr El-Sheikh, Tanta Univ., Egypt.

13. Steel, R.G.D. and J.H. Torrir, 1960. Principles and procedures of statistics. McGraw-Hill book company, Inc., New York.

14. Sultan, Aziza M.M., Eman M.R. Saleh, Samia E. Ali and H.A.El-Hoseiny, 2013. Determining relationship between morphological, some anatomical traits and phenols related to insect resistance in two crosses cotton. J. Plant Production, Mansoura Univ., vol. 4 (2): 239-248.

15. Zeina, A.M.A. 2002. Using biparental mating system to produce new promising recombination in cotton. Egypt. J. Agric. Res., 80(1): 325-340.

16. Zeina, A.M.A., A.A.M. Awad and E.A. El-Disouqi. 2001. Line $x$ tester analysis for heterosis and combining ability evaluated different level of soil salinity in cotton (Gossypium barbadense L.). J. Agric. Sci. Mansoura Univ., 26(6): 3603-3619.

17. Zhang,Z.S., L.I. Xianbi, Y. Xiao, M. J. Liu, S.L.Huang and F.X.Zang, 2003. Combining ability and heterosis between high strength lines and transgenic BT (Bacillus thuringiensis) boll worn- resistant lines in upland cotton (Gossypium hirsutum L.) Agric.Scie. in China 2 (1)13- 18. 


\section{تقييم بعض هجن القطن للصفات الاقتصادية}

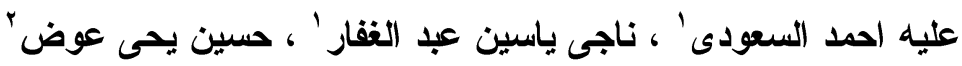

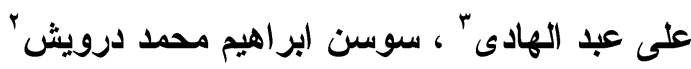

$$
\begin{aligned}
& \text { ا ـ كلبه الزر/عة - جامعة عبن شدس }
\end{aligned}
$$

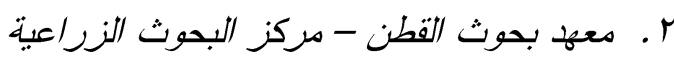

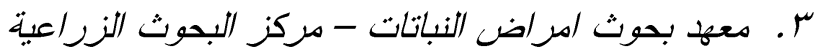

يهدف هذا البحث الى دراسة قوة الهجين ، القدرة على الائتلاف ، طبيعة الفعل الجينى ومعامل

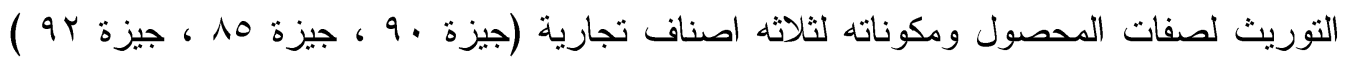

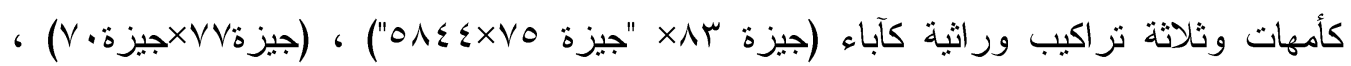

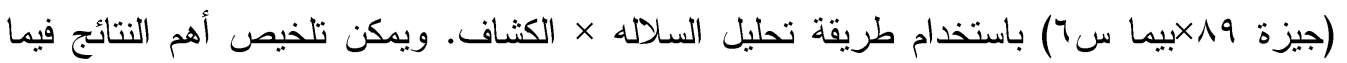

- - أظهرت التز اكيب الور اثية (الآباء و الهجن) اختلافات معنوية لجميع الصفات المدروسه. وقد

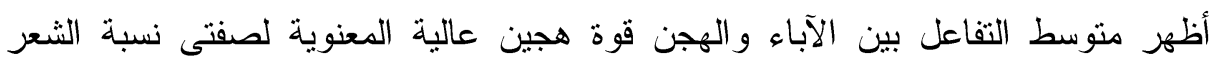
ودليل البذرة كما تباينت قوة الهجين بالنسبة لمتوسط الأبوين بين معنوية وعالية المعنوية.

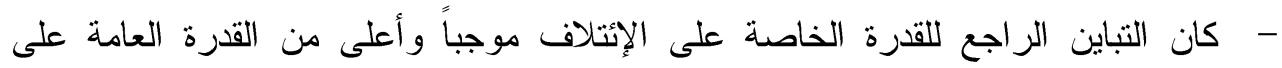

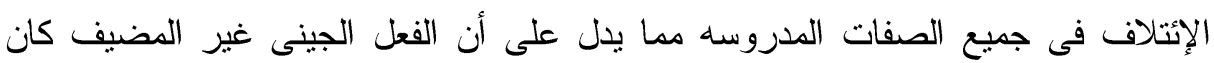
الأكثر أهمية فى ور اثثة هذه الصفات.

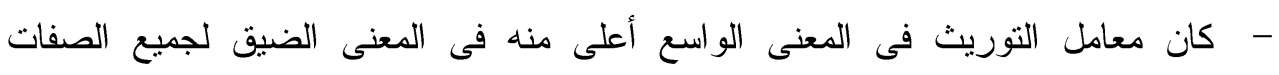

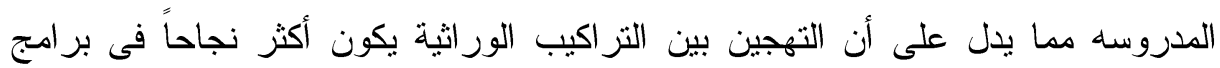
التربية. - كانت قيم معامل التوريث فى المعنى الضيق ضئيله جدا لصفات وزن البذرة ونسبه الثعر مما يدل على غياب الفعل المضيف بالنسبه لهاتين الصفتين. - يمكن الاستفادة من هذه الدراسة فى توجيه برامج التربية للحصول على أصناف متميزة بالنسبة لصفات المحصول ومكوناته عن طريق الانتخاب بين نباتات الجيل الأول للهجن المتميزة و المبشرة بتحسين ملحوظ لتلاك الصفات. 